\title{
Monika Sitarska-Buba
}

Uniwersytet Ekonomiczny we Wrocławiu

e-mail: monika.sitarska@ue.wroc.pl

\section{SYSTEMY III PLATFORMY JAKO KOLEJNY ETAP ROZWOJU SYSTEMÓW INFORMATYCZNYCH WSPIERAJĄCYCH PRZEDSIĘBIORSTWO}

\section{RD PLATFORM SYSTEMS AS THE NEXT STAGE OF DEVELOPMENT OF IT SYSTEMS SUPPORTING A COMPANY}

DOI: $10.15611 /$ ie.2017.3.08

JEL Classification: C88, M21

Streszczenie: Strategia digitalizacji przedsiębiorstw warunkuje zmiany zarówno w systemach IT, jak i w sposobach działania przedsiębiorstw. Jednym z kierunków rozwoju współczesnych aplikacji informatycznych są systemy III platformy, które integrują technologie wspierające media społecznościowe i mobilne, analizę danych oraz technologie chmury obliczeniowej. Celem artykułu jest prezentacja struktury systemów III platformy, omówienie poszczególnych technologii składowych oraz ich znaczenia dla tej klasy systemów. Systemy III platformy w swojej strukturze narzucają integrację w warstwie procesów biznesowych, usług oraz infrastruktury, kładąc nacisk na efekt synergii poszczególnych technologii. Wielopłaszczyznowa integracja technologiczna umożliwia tworzenie systemów biznesowych, które odpowiadają na wyzwania rynku globalnego, rozproszonego i generującego terabajty danych. Implementując kluczowe technologie i zapewniając bezpieczeństwo transakcji, systemy III platformy mogą efektywnie wspierać decydentów w procesach zarządzania.

Słowa kluczowe: Social, mobile, analytics, cloud, SMAC, systemy III platformy, bezpieczeństwo.

Summary: The goal of the article is to describe new wave of IT systems - SMAC oriented IT systems. The digital transformation of enterprises should be supported by new technology used in the proper way. SMAC oriented IT systems use synergy effect of 4 technologies: Social, Mobile, Analytics and Cloud to support digital transformation of the business. SMAC oriented IT systems require integration of the business processes, services and the infrastructure to reach the synergy effect that can be provided by key technologies. Digital enterprise has to be managed by IT systems that can adopt to changing environment, allow to learn from data collected within company and outside but also are able to build client long term engagement.

Keywords: Social, Mobile, Analytics, Cloud, SMAC, $3^{\text {rd }}$ platform systems, security. 


\section{Wstęp}

Wiele współczesnych przedsiębiorstw dostosowuje modele zarządzania oraz procesy biznesowe do transformacji cyfrowej, która towarzyszy nam od kilkunastu lat. Transformacja cyfrowa dotyczy każdej strefy działalności przedsiębiorstw, zmieniając dotychczasowe modele zachowań klientów oraz pracowników firm. Mając tego świadomość, współczesne przedsiębiorstwo powinno znaleźć efektywną ścieżkę wykorzystania nowych technologii do budowania własnej przewagi konkurencyjnej, ale także do adaptowania technologii cyfrowych w modelach sprzedażowych. Ponadto cyfryzacja dotyczy także wewnętrznych procesów w firmie, a więc stoją przed nią także wyzwania w zakresie zaangażowania własnych pracowników i budowania w nich przynależności do społeczności, którą stanowi firma.

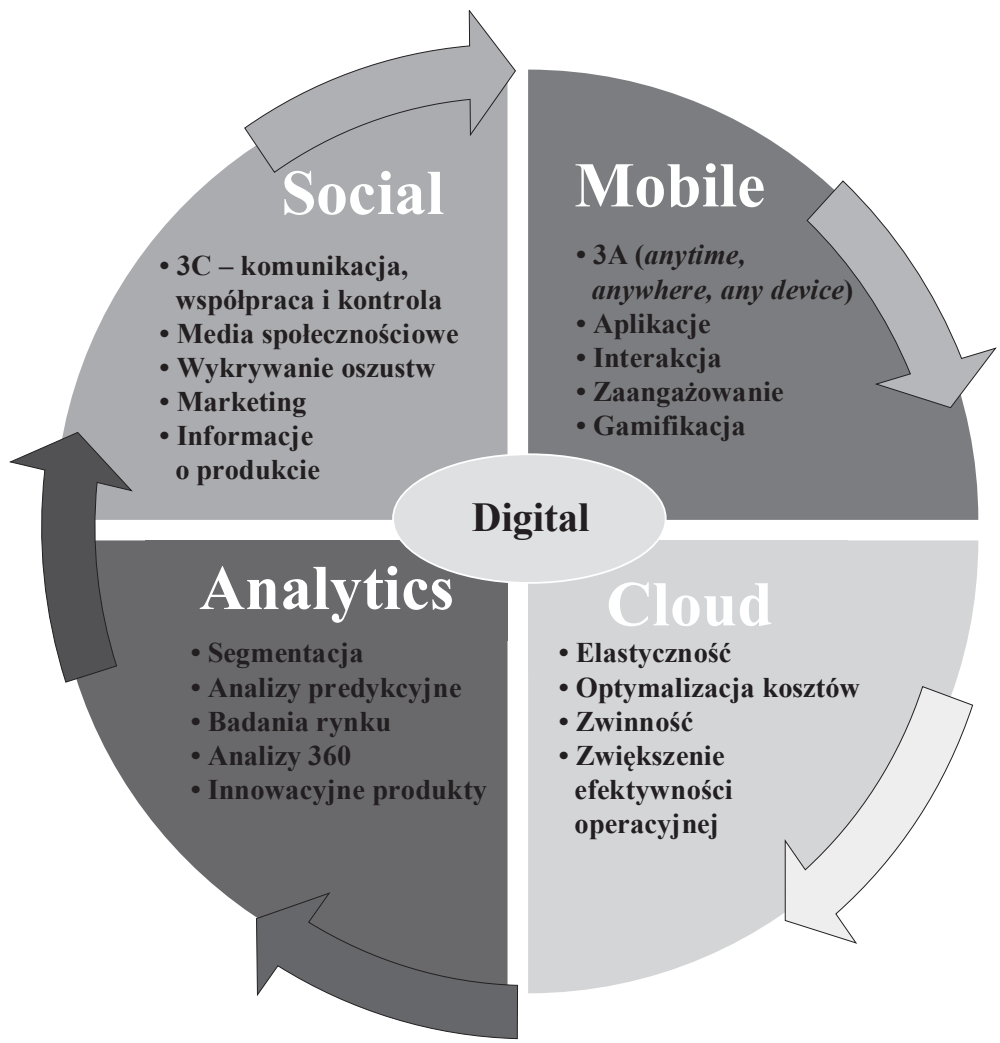

Rys. 1. Technologie tworzące systemy III platformy

Źródło: opracowanie własne na podstawie [EY 2015]. 
Celem artykułu jest prezentacja struktury systemów III platformy, omówienie poszczególnych technologii składowych oraz ich znaczenia dla tej klasy systemów. W artykule skoncentrowano się także na aspektach integracji poszczególnych warstw systemów III platformy.

Pojęcie systemów III platformy zostało wprowadzone przez firmę IDC (International Data Corporation) w roku 2010 i oznacza klasę systemów informatycznych, które integrują i wykorzystują efekt synergii czterech niezależnych technologii informatycznych: mediów społecznościowych, technologii mobilnych, analizy danych oraz chmury obliczeniowej. W literaturze anglojęzycznej systemy III platformy są opisywane jako systemy SMAC (social, mobile, analytics, cloud) - nazwa stanowi akronim pierwszych liter technologii składowych.

Na rys. 1 zobrazowano zależności, które przyczyniają się do zbudowania efektu synergii stanowiącego wartość dodaną systemów III platformy.

Przedsiębiorstwo cyfrowe, implementując systemy III platformy, wspiera proces zarządzania przedsiębiorstwem w takich aspektach, jak wzmocnienie zaangażowania klientów poprzez spersonalizowaną ofertę i komunikację, wykorzystując aplikacje mobilne, media społecznościowe oraz procesy e-commerce. Działania marketingowe mogą być zoptymalizowane poprzez implementacje mechanizmów pozycjonowania stron, algorytmów wyszukiwania na podstawie historii dotychczasowych zakupów oraz dostosowany przekaz reklamowy, który może być odbierany raczej jako porada niż jako tradycyjna reklama.

Systemy III platformy mogą być wykorzystywane w analizie danych klientów (customer intelligence), w obszarach rozwoju nowych rynków oraz produktów, w optymalizacji procesów biznesowych, determinują architekturę systemów IT wdrożonych w przedsiębiorstwie.

Proliferacja ustrukturalizowanych i nieustrukturalizowanych danych z urządzeń mobilnych, sensorów, mediów społecznościowych, programów lojalnościowych i ze ścieżek nawigacji po stronach internetowych dostarcza wiedzy, która umożliwia optymalizację procesów i operacji z wykorzystaniem danych generowanych przez klienta.

Wiedza płynąca $\mathrm{z}$ danych przetwarzanych i generowanych przez systemy III platformy powinna kształtować długoterminową strategię rozwoju przedsiębiorstwa, kierunki innowacji oraz model zarządzania.

\section{Charakterystyka kluczowych technologii systemów III platformy}

\subsection{Zastosowanie technologii społecznościowych w tworzeniu systemów III platformy}

Aspekt społeczny w systemach III platformy koncentruje się na technologiach, które zmieniły sposób komunikacji, współpracy oraz kontroli między firmą i jej klientami, ale także pomiędzy jednostkami w społeczeństwie (3C - communication, collaboration, control). 
Media społecznościowe wprowadziły istotną zmianę w platformach komunikacyjnych między ludźmi, prezentują nowe miejsca, gdzie użytkownicy odkrywają informacje, czytają je i dzielą się informacjami. Technologia i funkcje dostarczane przez media społecznościowe zmieniły dialog społeczny z monologu (jeden-do-wielu) w wielokierunkowy dialog (wiele-do-wielu). Portale społecznościowe, takie jak Facebook, LinkedIn czy Twitter, pokazują nowy sposób, w jaki poszczególne jednostki oraz firmy mogą współpracować i komunikować się ze sobą, niejednokrotnie na płaszczyźnie globalnej. Im bardziej wzrasta liczba aktywnych użytkowników Internetu i samych sieci społecznościowych, tym bardziej zwiększa się znaczenie wdrożenia narzędzi społecznościowych w procesie budowania marki oraz kreowania zaangażowanej społeczności klientów wokół firmy. Media społecznościowe nie są ograniczone do sieci społecznościowych takich jak Facebook, w ich skład wchodzą także YouTube, blogi, strony geolokacyjne oraz inne sposoby aktywności w sieci.

Badania prowadzone przez portal statista.com, zaprezentowane na rys. 2, pokazują, że różnego typu media społecznościowe gromadzą miliony aktywnych użytkowników dziennie, co stanowi ogromny potencjał komunikacyjny na płaszczyźnie biznesowej.

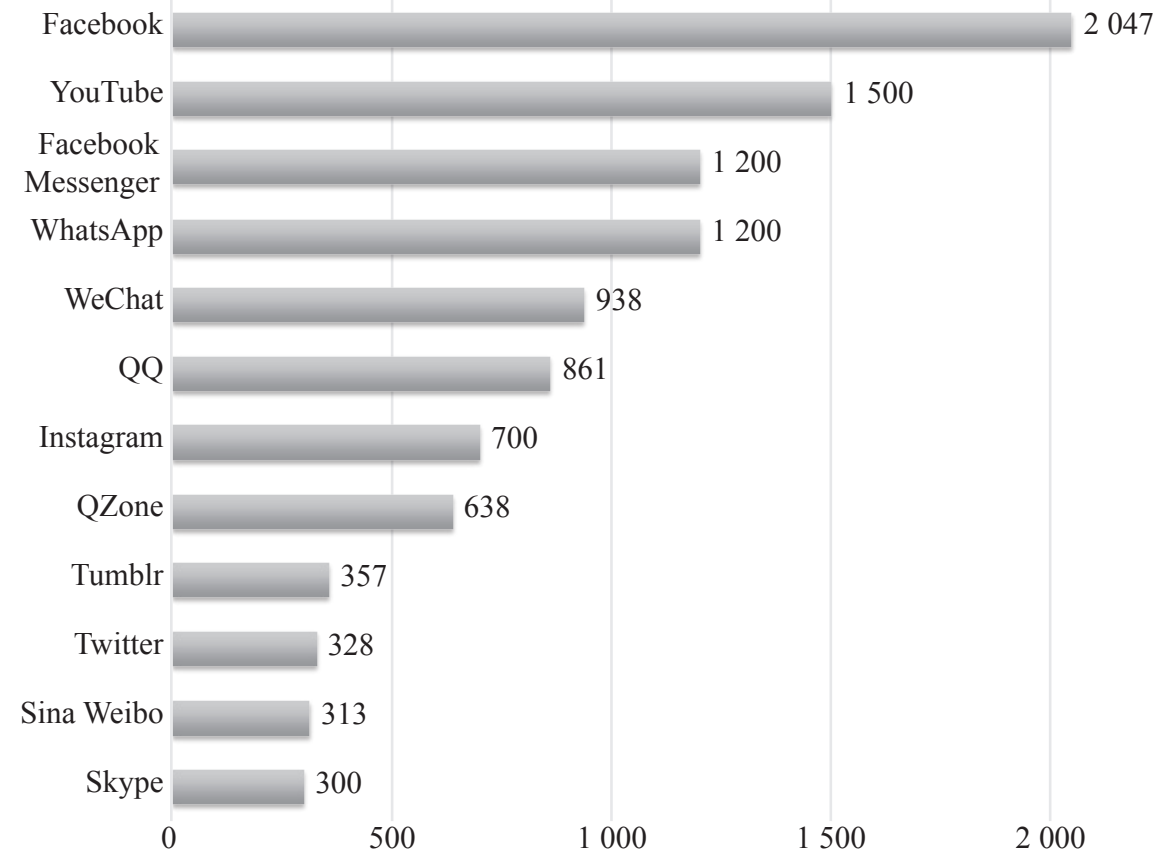

Rys. 2. Liczba aktywnych użytkowników mediów społecznościowych (w mln) Źródło: opracowanie własne na podstawie [STATISTA01 2017]. 
Media społecznościowe otwierają nowe kanały komunikacji i interakcji pomiędzy firmami oraz ich klientami. Model cyfrowy (digital model) narzuca zmiany w tradycyjnym postrzeganiu roli klienta, ale także roli pracownika danych organizacji.

Jeśli klient przeciętnej firmy dużą część swojego czasu spędza, korzystając ze smartfona, to dla niego naturalnym procesem będzie poszukiwanie dostępnych ofert właśnie poprzez to medium. Ale zanim wybierze odpowiednią ofertę, może sprawdzić profil firmy na Facebooku, zweryfikować opinie innych klientów na temat oferty, obsługi oraz cen. Klient wzbogacony o kluczowe dla siebie informacje $\mathrm{w}$ procesie decyzyjnym dokona wyboru.

Utworzenie profilu przedsiębiorstwa w rzeczywistości cyfrowej jest procesem długofalowym, który warto poprzeć analizą danych klientów oraz ich dotychczasowych zachowań. Wyniki analizy profili klientów, które można uzyskać, korzystając $\mathrm{z}$ tradycyjnych kanałów sprzedaży, pozwalają na predykcję nowych cyfrowych sposobów komunikacji z klientami i dodatkowo, co jest ważniejsze, na prezentowanie indywidualnej oferty. Komunikacja z klientami może się odbywać w czasie rzeczywistym, a to istotnie wpływa na przebieg procesu biznesowego w każdym przedsiębiorstwie.

Przykładem implementacji zachowań społecznościowych na gruncie biznesowym są blogi korporacyjne, które zastępują komunikację z pracownikami drogą mailową. Przyczyn takiego stanu rzeczy jest kilka. Publikując post na blogu, można w szybki sposób zweryfikować jego oddziaływanie na daną społeczność. Pracownicy mają możliwość skomentowania danej informacji, udzielenia informacji zwrotnej, co w konsekwencji pozwala na ocenę danej zmiany i skorygowanie kierun$\mathrm{ku}$, jeśli jest on błędny. Innym argumentem przemawiającym za blogami jest ich powszechne wykorzystanie w sferze prywatnej na portalach społecznościowych. Jeśli ta forma dialogu jest chętnie wykorzystywana przez pracowników, to można założyć, że równie pozytywny efekt będzie można osiągnąć w komunikacji wewnątrzfirmowej. Mechanizmy te pozwalają budować zaangażowaną społeczność wokół firmy, a im bardziej są zaangażowani pracownicy, tym bardziej będą oni widoczni w przestrzeni cyfrowej, budując pozytywny wizerunek w otoczeniu przedsiębiorstwa. Blogi mogą służyć także do dzielenia się wiedzą i doświadczeniem poszczególnych pracowników, a co za tym idzie - stanowią nowe kanały edukacji wewnątrzfirmowej.

Media społecznościowe implementowane w systemach III platformy zmieniają procesy biznesowe $\mathrm{w}$ przedsiębiorstwie. Przedsiębiorstwo staje się widoczne w obszarach, które do tej pory były zarezerwowane do kontaktów i komunikacji na płaszczyźnie prywatnej, a nie biznesowej. Efektywne wykorzystanie mediów społecznościowych w systemach III platformy umożliwia przedsiębiorstwom zmiany w zakresie implementacji nowych strategii zarządzania dostosowujących przedsiębiorstwo do występującej transformacji cyfrowej. 


\subsection{Zastosowanie technologii mobilnych w tworzeniu systemów III platformy}

Drugi filar systemów III platformy stanowią technologie mobilne. Zmianę wprowadzoną przez te technologie można ująć w trzech aspektach: informacja jest dostępna zawsze, w dowolnym miejscu i na dowolnym urządzeniu (3A - anytime, anywhere, any device). Podejście to $\mathrm{w}$ rewolucyjny sposób wprowadza nowe reguły w zachowaniach pracowników oraz klientów. Procesy biznesowe wychodzą poza ramy i ograniczenia wynikające $z$ dostępności aplikacji tylko wewnątrz sieci firmowej i tylko na komputerach czy laptopach stacjonarnie w biurze. Technologie mobilne dostarczają nowego wymiaru dostępności do zasobów cyfrowych i aplikacji w dowolnym miejscu i dowolnym czasie. Dla współczesnego przedsiębiorstwa stanowi to wyzwanie na płaszczyźnie zarządzania i transformacji cyfrowej.

Urządzenia mobilne zmieniły sposób, w jaki użytkownicy korzystają z zasobów cyfrowych. Ostatnie kilka lat pokazuje znaczne zwiększenie się liczby użytkowników smartfonów. Prognozuje się, że do 2018 roku 36\% ziemskiej populacji będzie używała urządzeń mobilnych, co stanowi wzrost o $26 \%$ w porównaniu z 2011 rokiem, kiedy jedynie $10 \%$ populacji używała smartfonów [STATISTA02 2017]. Na rys. 3 zaprezentowano trend wzrostowy liczby użytkowników smartfonów do roku 2020 .

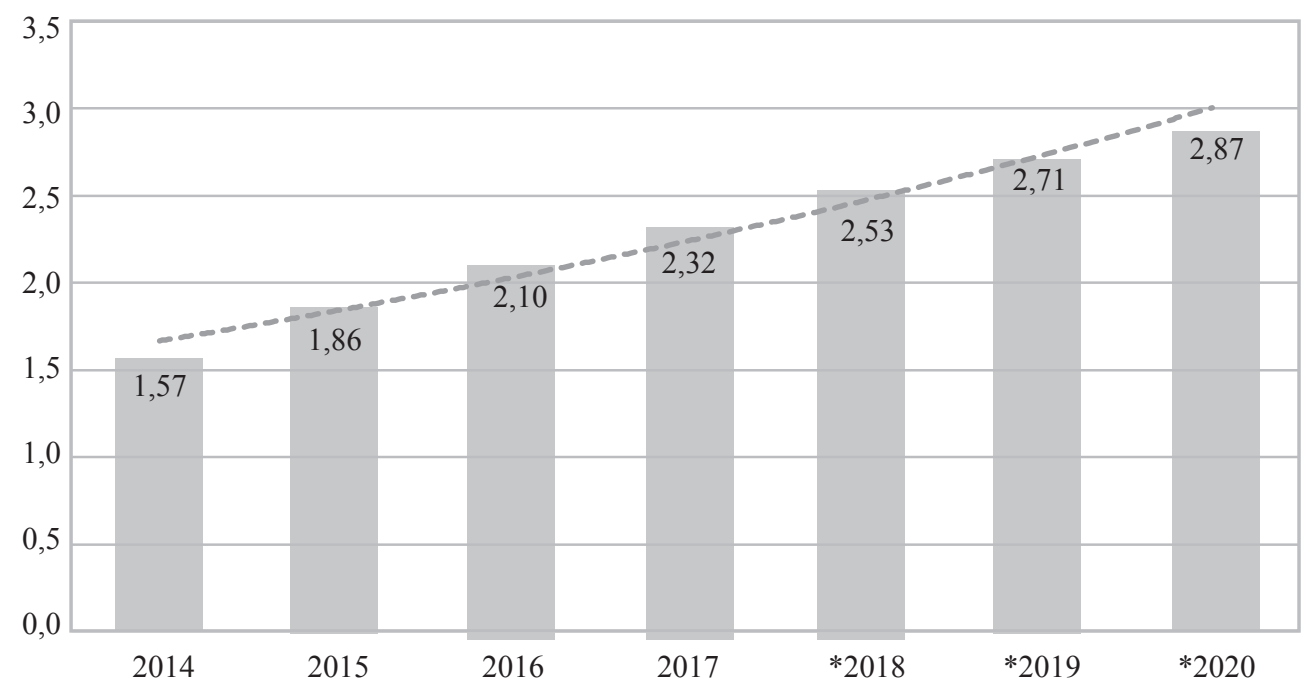

Rys. 3. Liczba aktywnych użytkowników smartfonów (w mld)

Źródło: opracowanie własne na podstawie [STATISTA02 2017].

Dane statystyczne pokazują na coraz większe znaczenie dla biznesu technologii mobilnych, które w najbliższych latach staną się dominującym narzędziem pracy, wymiany informacji, rozrywki oraz dokonywania transakcji. Dlatego warto 
zwrócić uwagę na jeszcze jedno zjawisko, którego popularność wzrasta w przedsiębiorstwach: bring your own device (BYOD) - umożliwienie pracownikowi korzystania ze swojego urządzenia w celach służbowych. Technologie mobilne zmieniły zachowania i zwyczaje przeciętnych, statystycznych klientów, ale także zachowania i zwyczaje pracowników. Nie każda firma udostępnia pracownikom telefony służbowe, a jeśli udostępnia, to nie zawsze są one nowoczesnymi smartfonami. Dlatego też wychodząc naprzeciw potrzebom pracowników, niektóre przedsiębiorstwa implementują model BYOD, pozwalając, aby urządzenia prywatne zostały wchłonięte w korporacyjną infrastrukturę. Dostęp do poczty mailowej oraz do innych zasobów firmowych czy aplikacji zwiększa elastyczność pracowników oraz ich dostępność. Jednak dla firmy stanowi to wyzwanie na płaszczyźnie bezpieczeństwa i ochrony danych poufnych przed niepowołanym dostępem. Jedną z konsekwencji jest zwiększenie nakładów na bezpieczeństwo i certyfikację urządzeń, zanim zostaną one zarejestrowane w firmowej sieci.

Urządzenia mobilne wynoszą procesy biznesowe poza granice przedsiębiorstwa i poza standardowe godziny pracy. Stwarza to nowe możliwości w zakresie automatyzacji procesów biznesowych takich jak sprzedaż czy promocja i reklama. Dostarczenie spersonalizowanej aplikacji mobilnej wyświetlającej kontent pożądany przez klienta jest kolejnym kanałem dystrybucji dla firmy. Z drugiej strony pracownicy firmy stają się bardziej mobilni i dłużej dostępni, mogąc korzystać na swoich urządzeniach z aplikacji firmowych. Dalszą konsekwencją jest rozmycie definicji miejsca pracy. Pracownicy, korzystając z dostępów zdalnych, mogą świadczyć pracę $\mathrm{z}$ dowolnej lokalizacji.

Warto także podkreślić, że urządzenia mobilne oraz ich użytkownicy stanowią doskonałe źródło danych dla analiz generowanych przez trzecią grupę technologii wchodzących w skład systemów SMAC - analitykę.

\subsection{Znaczenie technologii analitycznych w tworzeniu systemów III platformy}

Analiza danych była i jest obecna w większości przedsiębiorstw. Dane, informacje i wiedza powstająca w wyniku ich analizy przyczynia się do zmniejszenia ryzyka podejmowania błędnych decyzji przez menedżerów i ich zespoły. Dlaczego analiza stała się na tyle istotna, że stanowi integralną część nowo budowanych systemów trzeciej platformy? Po pierwsze, ilość danych dostępnych do analizy w każdej przeciętnej firmie znacznie wzrosła, a po drugie, dostępne technologie pozwalają na analizę danych nieustrukturalizowanych, rozproszonych i zróżnicowanych.

Integracja mediów społecznościowych i technologii mobilnych w strukturach systemów informatycznych przedsiębiorstwa stworzyła potrzebę integrowania technologii analitycznych z nowymi źródłami danych takimi jak posty na blogach korporacyjnych i publicznych (Facebook czy Twiter), obrazy, zdjęcia czy uporządkowane dane zgromadzone w bazach danych firmy (systemy ERP, CRM).

Według Instytutu Gartnera „Big Data jest to zbiór danych charakteryzujący się dużą objętością, dużą różnorodnością oraz dużą prędkością zmian, który wymaga 
efektywnych kosztowo i innowacyjnych metod i form przetwarzania danych, które udoskonalą procesy decyzyjne i automatyzację" [BIGDATA 2017]. W literaturze przedmiotu można spotkać różne definicje pojęcia Big Data, jednak większość z nich wskazuje na pięć integralnych cech: objętość (volume) dotyczy ilości generowanych danych, która jest liczona w exa-, zetta- czy yottabajtach; prędkość (velocity) wskazuje na fakt, że dane są generowane wyjątkowo szybko, w sposób ciągły, a zbiory danych są transformowane w wyniki niemal w czasie rzeczywistym; różnorodność (variety) zakłada, że dane pochodzą z różnych źródeł, takich jak systemy informatyczne, urządzenia, media społecznościowe; wiarygodność (veracity) koncentruje się na źródłach pochodzenia danych oraz ich jakość, a wartość (value) oznacza, na ile dane są przetwarzane w użyteczne informacje i wiedzę, która doskonali procesy decyzyjne na różnych szczeblach zarządzania [Marry 2014].

Technologia analizy danych (Big Data) stała się elementem niezbędnym i integralnym systemów III platformy. Według prognoz do roku 2020 ilość generowanych danych wzrośnie do 35 zetta bitów, co stanowi wzrost o $348 \%$ w porównaniu z rokiem 2015 [BIGDATA 2017].

Technologie Big Data, wyposażone w algory tmy przetwarzania, sztuczną inteligencję oraz w funkcje machine learning, pozwalają z tego chaosu informacji wydobywać trendy, zależności czy mapy powiązań, co umożliwia firmom podejmowanie właściwych decyzji na podstawie danych o wiele pełniejszych niż dotychczas.

Warto zwrócić uwagę na tendencje rozwojowe w systemach analitycznych, które stają się coraz łatwiejsze w obsłudze dla użytkowników niemających wiedzy technicznej ani statystycznej.

IBM Watson Analytics jest produktem, który za pomocą przyjaznego interfejsu opartego na technice drill down pozwala w kilku krokach przeprowadzać analizy biznesowe. Wiedza techniczna jest istotna w pierwszym etapie implementacji, gdzie należy zbudować warstwę analityczną, zdefiniować źródła danych oraz algorytmy ich przetwarzania. Korzystanie z narzędzia nie wymaga wiedzy statystycznej ani informatycznej, gdyż interfejs pozwala nam zadawać pytania w języku naturalnym, które następnie są przekształcane na propozycje analiz. Po wprowadzeniu pytania, co jest widoczne na rys. 4, aplikacja wyświetla proponowane raporty, które najbardziej odpowiadają zdefiniowanemu problemowi. Algorytmy wbudowane w silnik Watson Analytics „tłumaczą” słowa kluczowe z pytania na nagłówki dostępnych danych w pliku źródłowym. Jest to przykład aplikacji kognitywnej, co oznacza, że każda analiza zwiększa poprawność i trafność algorytmów oraz ich dopasowanie do zadawanych pytań. 


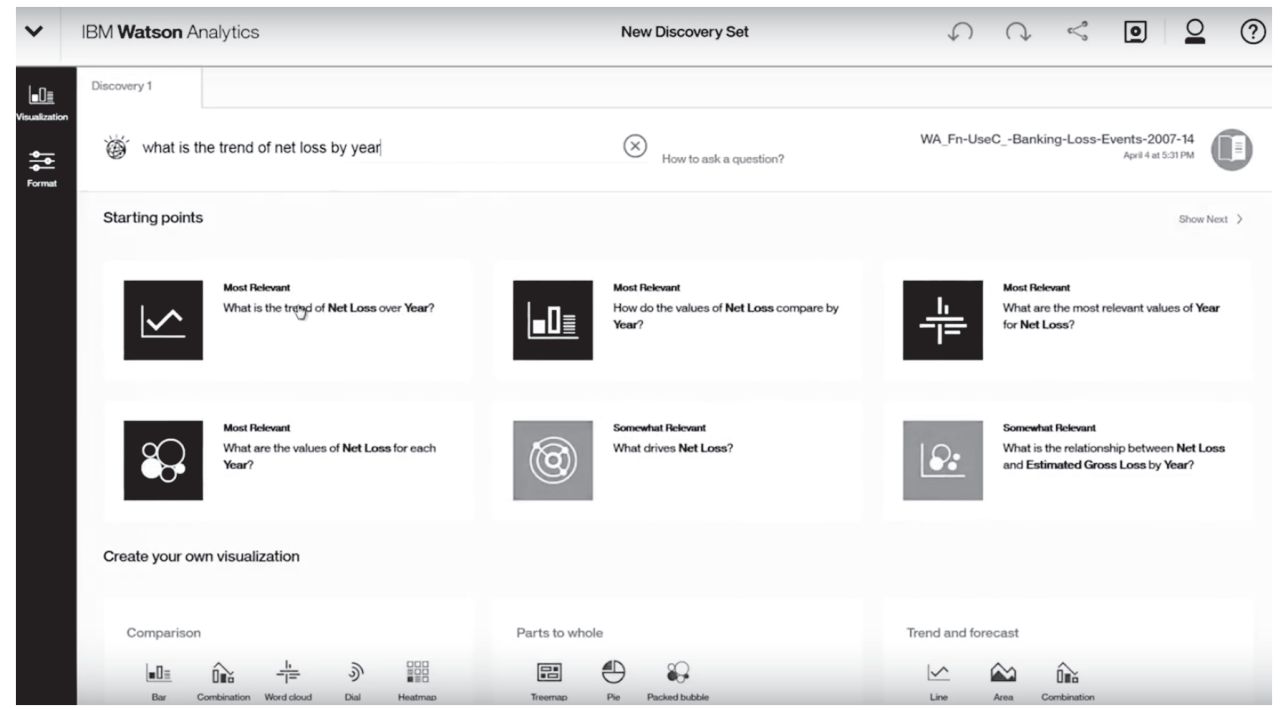

Rys. 4. Interfejs aplikacji IBM Watson Analytics - ekran umożliwiający wprowadzanie zapytań Źródło: [WATSON 2017].

Użytkownik, mając kilka propozycji analiz wyświetlonych przez Watson Analytics, dokonuje wyboru i przechodzi do szczegółowych danych prezentowanych graficznie.

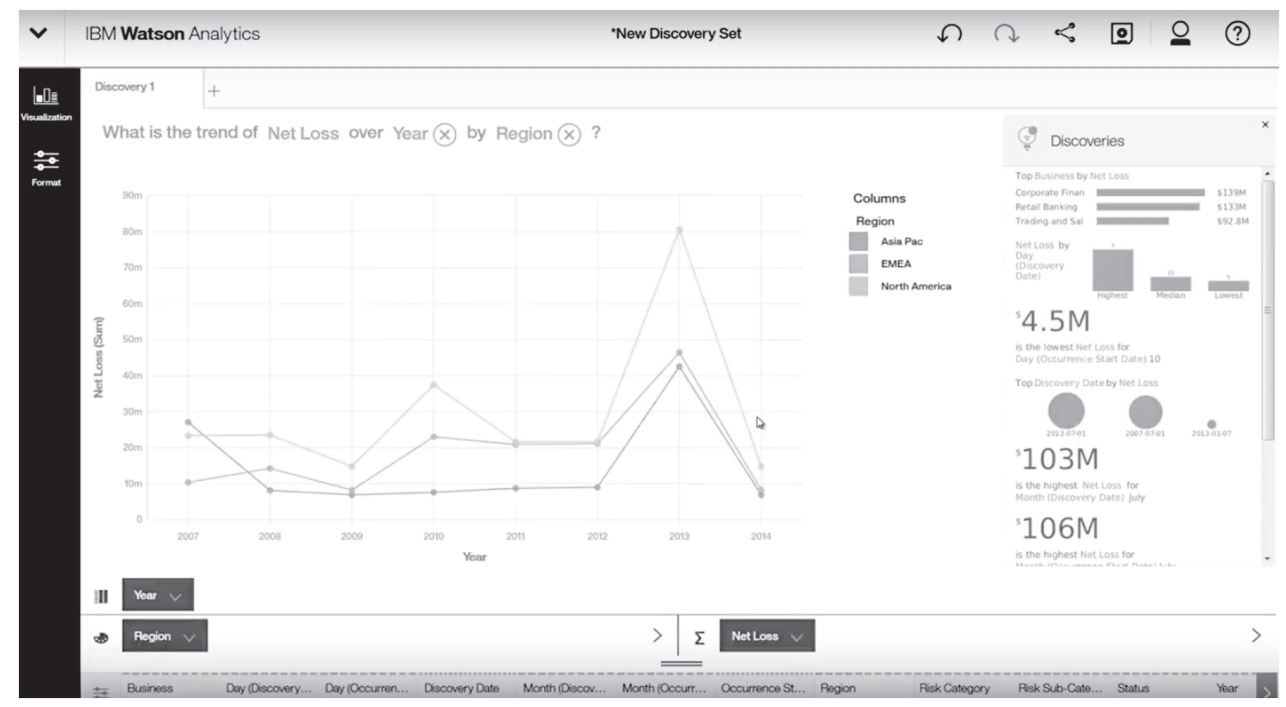

Rys. 5. Interfejs aplikacji IBM Watson Analytics - ekran wyświetlający przykład analizy Źródło: [WATSON 2017]. 
Poza graficzną prezentacją trendu, aplikacja przeszukuje też dane w celu zidentyfikowania kluczowych zmiennych (jak np. lista klientów, którzy wygenerowali najsłabsze wyniki w badanym okresie), wzorców zachowań, zmiennych zależnych czy innych czynników, które mogły wpłynąć na wynik analizy.

IBM Watson Analytics jest przykładem kierunku, w którym zmierzają aplikacje analityczne. Przyjazny interfejs wspierający język naturalny mówiony i pisany staje się transparentny dla zaawansowanych algorytmów statystycznych, machine learing oraz sztucznej inteligencji. Pracownik może analizować dane swoich klientów wynikające $\mathrm{z}$ ich aktywności w mediach społecznościowych, dane generowane przez aplikacje mobilne, weryfikować trendy i prognozować z coraz większą skutecznością. Bez narzędzi analitycznych zintegrowanych z pozostałymi technologiami SMAC efekt synergii nie mógłby zostać osiągnięty. Systemy III platformy, dostarczając użyteczne informacje i wiedzę decydentom, stają się istotnym narzędziem wspierającym zarządzanie przedsiębiorstwem.

\subsection{Zastosowanie technologii chmury obliczeniowej w systemach III platformy}

Czwartą technologią będącą elementem składowym systemów III platformy jest chmura obliczeniowa (cloud computing). Technologia chmury obliczeniowej pozwala na dostarczenie zasobów oraz aplikacji w postaci usługi IT na żądanie klienta $\mathrm{w}$ modelu rozliczeniowym dostosowanym do rzeczywistego zużycia (pay-as-you-go). Implementacja chmury obliczeniowej w przedsiębiorstwie wiąże się ze strategią wirtualizacji i cyfryzacji danego przedsiębiorstwa. Od klasycznej infrastruktury IT, wymagającej inwestycji finansowych, strategia informatyzacji przedsiębiorstwa migruje w kierunku wirtualnych usług IT opartych na systemach kognitywnych oraz zautomatyzowanych procesach biznesowych.

Wraz z pozostałymi technologiami systemów III platformy, jak: media społecznościowe, technologie mobilne i analityka, chmura obliczeniowa jest warunkiem koniecznym do dokonania transformacji cyfrowej przedsiębiorstwa. Chmura dostarcza infrastrukturę, gdzie procesy biznesowe uwzględniające modele społecznościowe, technologie mobilne, a co najważniejsze - wykorzystujące wiedzę płynącą $\mathrm{z}$ analiz biznesowych mogą być efektywnie implementowane.

Według National Institute of Technology (NIST) chmura obliczeniowa charakteryzowana jest przez pięć głównych składowych: pulę zasobów, automatyzację i wirtualizację tych zasobów, szeroki dostęp do sieci, elastyczność oraz mierzalność usług (por. [CISCO02 2016, s. 27]).

Ze względu na to, czy zasoby chmury obliczeniowej są współdzielone z innymi klientami, czy dedykowane dla jednego podmiotu, mamy do czynienia z chmurą prywatną lub publiczną. Jeśli firma buduje centrum obliczeniowe w pełni dedykowane do obsługi wewnętrznych usług IT, mamy do czynienia z chmurą prywatną, gdzie zasoby i procesy są $\mathrm{w}$ pełni kontrolowane przez ten podmiot, który korzysta ze wszystkich zalet, jakie daje wirtualizacja, a jednocześnie nie ponosi ryzyka związanego z przechowywaniem danych na serwerach podmiotów zewnętrznych. Ko- 
rzystanie z zasobów chmury prywatnej odbywa się wewnątrz sieci korporacyjnej, a więc zwiększa to bezpieczeństwo danych i transakcji.

Chmura publiczna jest usługą oferowaną przez dostawców takich jak AT\&T, Verizon, Amazon AWS, Microsoft Azure, Salesforce czy Google. Z dostępnego pakietu usług oraz modeli biznesowych klient wybiera ten, który spełnia jego oczekiwania biznesowe. W odróżnieniu od chmury prywatnej to usługodawca zarządza pulą zasobów i udostępnia je klientowi na podstawie podpisanej umowy. Dostęp do wirtualnych zasobów jest realizowany poprzez zewnętrznych usługodawców sieciowych, więc aspekt związany z bezpieczeństwem danych i transakcji staje się kluczowy.

W literaturze przedmiotu można spotkać szeroki opis modeli biznesowych, z jakich może korzystać przedsiębiorstwo, implementując technologie chmury obliczeniowej (por. [Mateos, Rosenberg 2011, s. 39-42]). Najpopularniejsze warstwy chmury obliczeniowej to:

1. Infrastruktura jako usługa (IaaS) - obejmuje zasoby IT, w skład których wchodzą infrastruktura sieciowa, przestrzeń dyskowa, wirtualne serwery (CPU), oraz warstwę wirtualizacji (np. VMWare) odpowiedzialną za transformację zasobów fizycznych na wirtualne.

2. Platforma jako usługa (PaaS) - w przypadku PaaS dostawca dodatkowo poza infrastrukturą dostarcza system operacyjny oraz midleware niezbędny do zainstalowania aplikacji klienckich.

3. Oprogramowanie/aplikacja jako usługa (SaaS) - jeśli klient zdecyduje się na wariant SaaS, to odpowiedzialność za oprogramowanie i dane leży po stronie dostawcy. Przykładem coraz bardziej popularnych aplikacji dostępnych w modelu SaaS jest Office 365 firmy Microsoft oferujący wersję online popularnych aplikacji biurowych.

Postępująca transformacja cyfrowa przedsiębiorstw, wspierana przez systemy III platformy, otwiera przed usługodawcami kolejne kierunki wirtualizacji. Firma IBM proponuje swoim klientom nowy model chmury obliczeniowej: Enterprise IT as a Service (EITaaS), w którym warstwa wirtualizacji dotyczy klasycznych systemów wspierających zarządzanie przedsiębiorstwem, takich jak ERP i CRM.

Model ten zakłada, że dostawca (wewnętrzny lub zewnętrzny) dysponuje ofertą usług IT dla biznesu, które wspierają i optymalizują procesy biznesowe. Katalog usług jest zdefiniowany na podstawie rzeczywistych potrzeb wynikających z zadań realizowanych przez poszczególne działy przedsiębiorstwa. Funkcje klasycznych systemów ERP są zastąpione przez usługi, które mogą być dostarczone na żądanie w odpowiednim momencie. Przykładem takiej usługi może być już wcześniej wspominana aplikacja: IBM Watson Analytics.

Firma IBM wychodzi naprzeciw oczekiwaniom klientów, których infrastruktura IT składa się z wielu aplikacji i procesów IT zorientowanych na gromadzenie danych transakcyjnych i analitycznych. Wiele firm stoi przed dylematem, jak przekształcić obecną infrastrukturę w systemy III platformy zorientowane na innowa- 
cje, zaangażowanie klienta końcowego oraz szybką adaptację do zmieniających się warunków otoczenia. Wydaje się, że model EITaaS może być odpowiedzią na tę potrzebę, ponieważ ciężar wyboru technologii, modeli biznesowych oraz sposobu świadczenia usługi jest przesunięty na dostawcę, który na podstawie warunków biznesowych klienta powinien zbudować optymalne środowisko IT wspomagające transformację cyfrową.

Framework EITaaS zaprezentowano na rys. 6 Infrastrukturę techniczną tworzy tam hybryda tradycyjnych systemów IT, chmury prywatnej oraz publicznej. Kolejną warstwę stanowi orkiestracja, a więc algorytmy definiujące zasady zarządzania infrastrukturą oraz zasady zarządzania usługami i ich doboru. Algorytmy orkiestracji definiowane są przez dostawcę (brokera) całego portfolio usług. Trzecią warstwę stanowią usługi wewnętrzne oraz usługi dostarczane przez usługodawców 3rd Party. Ostatnią warstwę stanowią usługi w rozumieniu biznesowym, które integrują poszczególne warstwy, a jednocześnie są dla użytkownika końcowego transparentne technologicznie. Przykładem usługi biznesowej mogą być dekretacja dokumentów, drukowanie, poczta elektroniczna, ofertowanie, realizacja kampanii marketingowej, CRM czy ERP. Warstwami pomocniczymi, ale jednocześnie integralnymi, są: bezpieczeństwo, automatyzacja, analityka wykorzystująca algorytmy kognitywne.

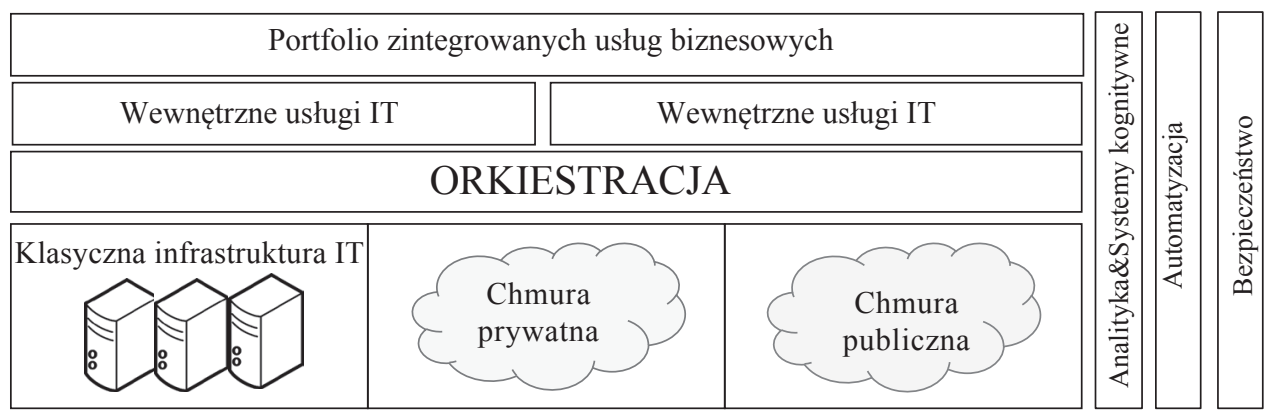

Rys. 6. Framework Enterprise IT as a Service

Źródło: opracowanie własne na podstawie [IBM 2017].

Framework EITaaS może być początkiem definiowania architektury systemów III platformy. Przedsiębiorstwa chcące wejść na drogę transformacji cyfrowej stoją przed wyzwaniem, jak zintegrować kluczowe technologie SMAC, jak zbudować strategie IT, aby osiągnąć efekt synergii. EIT as a Service wskazuje kierunki integracji i rozwoju, jednak to wiedza biznesowa powinna być główną siłą, która będzie kształtowała portfolio usług, technologie i rodzaje analiz dostarczanych przez systemy kognitywne. 


\subsection{Bezpieczeństwo jako integralny aspekt systemów III platformy}

Firma IBM dodaje jeszcze jeden integralny wymiar do systemów III platformy, jakim jest security, czyli bezpieczeństwo (CAMSS - cloud, analytics, mobile, social, security). Trudno się nie zgodzić z tym podejściem, skoro wzrasta ilość transakcji utrzymywanych w chmurze obliczeniowej, miliardy danych są przetwarzane w systemach analitycznych i tysiące pracowników korzysta z systemów biznesowych za pomocą swoich urządzeń mobilnych.

Potencjalne zagrożenia, które się z tym wiążą, wymagają od zarządu firmy coraz większej świadomości związanej z zasadami bezpieczeństwa. Jeśli firma chce odnieść korzyści wynikające z efektu synergii, jakie dają technologie SMAC, drugie S (security) staje się niewidoczną, ale integralną ich częścią.

Zabezpieczenie transakcji elektronicznych przed atakami cyfrowymi jest konieczne $z$ uwagi na niebezpieczeństwo narażenia firmy i jej klientów na utratę danych, a co za tym idzie - środków finansowych. Dla użytkownika mechanizmy zabezpieczeń są transparentne i niewidoczne. Natomiast protokoły bezpieczeństwa i klucze szyfrujące zabezpieczają każdą pojedynczą transakcję tak, aby była zrealizowana zgodnie z przeznaczeniem.

Większość kadry menedżerskiej jest świadoma wyzwań, jakie stanowi brak odpowiedniej polityki bezpieczeństwa. Braki w zakresie specjalistycznej kadry posiadającej wiedzę i kompetencje w zakresie technologii bezpieczeństwa jest faktem i dlatego firmy poszukują dostawców tego typu usług w modelu outsourcingowym. Odpowiednie zarządzanie ryzykiem oraz zapobieganie zagrożeniom cyfrowym stanowi istotny czynnik doboru technologii kształtujących systemy III platformy.

Ataki w cyberprzestrzeni ewoluowały z ataków once-in-a-while, czyli takich, które występowały raz na jakiś czas, w kierunku ciągłego zagrożenia oraz ataków ciągłych, ukierunkowanych i w pełni adaptacyjnych.

Taki stan wymaga synchronizacji technologii bezpieczeństwa z pozostałymi technologiami SMAC, aby można było budować bezpieczne środowisko cyfrowe obejmujące: modernizację bezpieczeństwa operacyjnego, zaawansowaną ochronę przed zagrożeniami cyfrowymi oraz ochronę danych krytycznych dla przedsiębiorstwa.

\section{Systemy III platformy jako narzędzie wspomagające przedsiębiorstwo}

Każda z omówionych technologii jest popularna i wykorzystywana w praktyce biznesowej. Kluczowym pytaniem jest to, w jaki sposób te niezależne technologie powinny być zintegrowane procesowo, architektonicznie oraz narzędziowo, aby tworzyły spójny system informatyczny wspierający zarządzanie przedsiębiorstwem. Założeniem systemów III platformy jest wykorzystanie efektu synergii czterech niezależnych technologii, który powinien być zintegrowany ze strategią przedsię- 
biorstwa oraz implementowany na poziomie procesów biznesowych. Wiedza, umiejętnie pozyskana, przetworzona i dostarczona przez systemy III platformy, wspomaga decydentów w podejmowaniu krytycznych decyzji na każdym szczeblu zarządzania. Należy zwrócić także uwagę na to, że, po pierwsze, technologia umożliwia rozszerzenie procesów biznesowych poza fizyczne granice przedsiębiorstwa i standardowy czas pracy, po drugie zaś stwarza nowe kanały komunikacji z klientem oraz jest w stanie personalizować ofertę, wykorzystując nowe źródła danych, rozszerzając dotychczasowe analizy skoncentrowane głównie na historii transakcji klienta.

Na rys. 7 zaprezentowano kluczowe zdaniem autorki elementy struktury systemów III platformy, podzielone na warstwy, które powinny tworzyć tę klasę systemów.

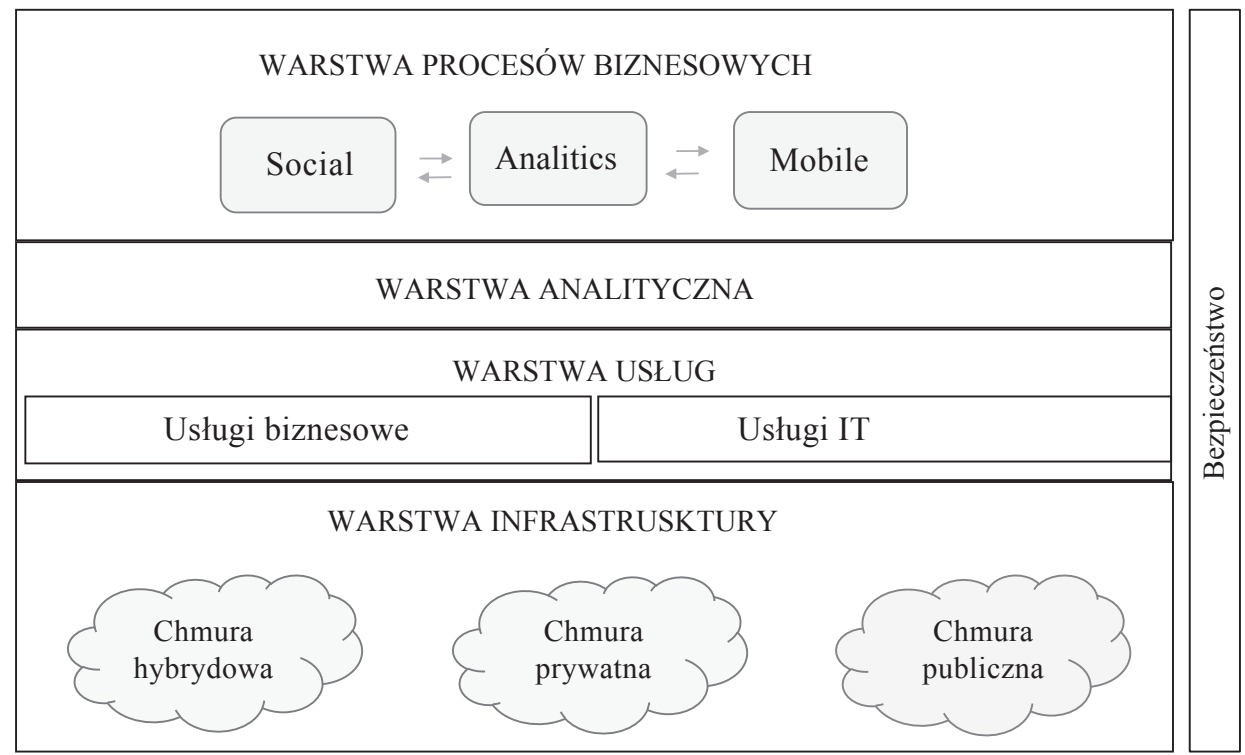

Rys. 7. Architektura systemów III platformy

Źródło: opracowanie własne.

Warstwa infrastruktury powinna być implementowana z założenia w technologii chmury obliczeniowej, aczkolwiek model chmury jest zależny od warstwy usług, które mają za zadanie wspomagać przedsiębiorstwo w definiowaniu procesów biznesowych. Jednak skalowalność, adaptacyjność w zmiennych warunkach otoczenia oraz elastyczność infrastruktury opartej na technologii chmury obliczeniowej to warunki konieczne budowania architektury systemów III platformy.

Model EITaaS można w tym przypadku wskazać jako najlepiej odzwierciedlający założenia systemów SMAC, ponieważ usługa jest definiowana w kontekście 
biznesowym i dookoła wartości biznesowej, którą ma dostarczyć klientowi. Ciężar rozumienia biznesu jest przesunięty także na dostawcę usług, który ma tak zdefiniować katalog usług, aby odpowiadały one strategii przedsiębiorstwa. Dostawca infrastruktury wspólnie z klientem (przedsiębiorstwem) definiuje optymalną grupę usług. Wiedza techniczna, którą posiada dostawca, połączona z wiedzą biznesową klienta tworzy dodatkowy efekt synergii.

Warstwą usług w tym rozumieniu stają się składowe procesów biznesowych, które w swej strukturze uwzględniają wiedzę płynącą z warstwy analitycznej, automatycznie dostosowując i udoskonalając swój przebieg. Warstwa analityczna jest zasilana przez terabajty danych pochodzących z klasycznych źródeł, takich jak systemy transakcyjne, ale także z nowych źródeł, które stanowią technologie mobilne i media społecznościowe. Odpowiednio zdefiniowane algorytmy przetwarzania danych wydobywają wiedzę ukrytą przez prognozowanie wzorców zachowań. Informacje publikowane przez klientów danej firmy na portalach społecznościowych stanowią doskonałe źródło danych o potencjalnych zainteresowaniach konsumpcyjnych. Warstwa analityczna systemów III platformy powinna uwzględniać media społecznościowe oraz dane mobilne jako jeden ze swoich zbiorów danych źródłowych generujących wiedzę i wpływających na procesy decyzyjne i długoterminową strategię przedsiębiorstwa cyfrowego.

Warstwa procesów biznesowych jest zasilana w wiedzę przez warstwę analityczną. Wiedza ta wpływa na przebieg, zakres oraz efektywność procesów biznesowych, a co za tym idzie - na efektywność przedsiębiorstwa. Można postawić tezę, że podstawowa rola systemów III platformy w zakresie wspierania procesu zarządzania przedsiębiorstwem podlega automatycznej optymalizacji i korekcji procesów biznesowych na podstawie wiedzy płynącej z warstwy analitycznej. Każda zmiana procesu, dzięki technologii, może być wprowadzona szybko i równie szybko możemy zweryfikować jej skutki, analizując dane praktycznie w czasie rzeczywistym.

Procesy biznesowe, implementując technologie mobilne, analityczne oraz media społecznościowe, wychodzą poza granice przedsiębiorstwa oraz poza standardowy model komunikacji z klientami i pracownikami. Dane wytwarzane przez media społecznościowe oraz technologie mobilne są analizowane w czasie rzeczywistym, a przetworzona wiedza jest dostępna w procesie decyzyjnym niemal natychmiast. Oznacza to, że przedsiębiorstwo w erze cyfrowej może korygować błędne decyzje niemalże w czasie rzeczywistym. Wydaje się, że dopiero systemy III platformy dostarczają tę przewagę konkurencyjną i wsparcie w procesie zarządzania przedsiębiorstwem cyfrowym.

Technologie bezpieczeństwa stanowią warstwę wspierającą, która pozwala na procesowanie transakcji w rozproszonym technologicznie i zróżnicowanym środowisku ery cyfrowej.

Systemy III platformy implementowane w przedsiębiorstwie zgodnie $\mathrm{z}$ jego strategią biznesową mogą stanowić skuteczne narzędzie wspierające zarządzanie przedsiębiorstwem. Integrując kluczowe technologie i uzyskując efekt syner- 
gii, przedsiębiorstwo podejmuje decyzje szybciej i efektywniej. Dodatkowo może rozważyć częściową automatyzację procesów, co w dłuższym okresie może także wpłynąć na wynik finansowy.

\section{Zakończenie}

Współczesne przedsiębiorstwa stoją w obliczu transformacji cyfrowej, która determinuje określone wymagania w stosunku do systemów informatycznych. Technologie informatyczne zmieniają sposób dostępu do danych, informacji i wiedzy, do kanałów komunikacji i miejsc realizacji transakcji biznesowych. Umożliwiają także automatyzację oraz cyfryzację obszarów, które dotychczas były domeną kontaktów bezpośrednich. Jednak inwestycje w kolejne rozproszone technologie nie przynoszą oczekiwanej stopy zwrotu.

Nowe generacje systemów informatycznych powinny wspierać przede wszystkim spójność strategii zarządzania służącej osiągnięciu celów biznesowych. Systemy III platformy w swojej strukturze narzucają integrację w warstwie procesów biznesowych, usług oraz infrastruktury informatycznej, kładąc nacisk na efekt synergii technologii mobilnych, analitycznych, chmury obliczeniowej oraz mediów społecznościowych. Wielopłaszczyznowa integracja technologiczna umożliwia tworzenie systemów biznesowych, ułatwiając menedżerom zarządzanie dzisiejszymi wyzwaniami rynku globalnego, rozproszonego i generującego terabajty danych. Implementując kluczowe technologie i zapewniając bezpieczeństwo transakcji, systemy III platformy mogą efektywnie wspierać decydentów w procesach zarządzania. Główne korzyści można analizować w kilku aspektach. Po pierwsze, systemy III platformy umożliwiają projektowanie nowych procesów biznesowych w obszarach sprzedaży i komunikacji z klientem, otwierając nowe kanały i media. Po drugie, dostarczając wielowymiarową wiedzę na temat każdego klienta, pozwalają korygować przebieg poszczególnych procesów niemal w czasie rzeczywistym. Warstwa analityczna w systemach III platformy, przetwarzając dane niemal w czasie rzeczywistym, stwarza możliwości odkrywania nowej nieuświadomionej wiedzy, ale także niemal natychmiast umożliwia weryfikację wprowadzanych zmian i doskonalenie ich procesów. Aby te zalety mogły być w pełni wykorzystane, infrastruktura systemów III platformy powinna być zbudowana w modelu EITaaS zintegrowanym z długoterminowymi celami strategicznymi przedsiębiorstwa.

W kolejnych badaniach autorka skoncentruje się na aspektach aplikacyjnych związanych z rozwojem systemów III platformy oraz na ich dalszej ewolucji w kierunku systemów kognitywnych. 


\section{Literatura}

ACCLAIM, 2017, Raport certyfikatów nadanych przez firmę pracownikom, https://www.youracclaim. com/profile/badges (8.11.2017)

BIGDATA, 2017, Big Data University, https://courses.cognitiveclass.ai/courses/course-v1:BigDataUniversity+BD0101EN+2016 T2/courseware/407a9f86565c44189740699636b4fb85/12eab34ec218468995e4d06566ef4a32/ (8.11.2017).

CISCO01, 2017, Raport: Cisco Visual Networking Index: Forecast and Methodology, 2016-2021, https://www.cisco.com/c/en/us/solutions/collateral/service-provider/visual-networking-index-vni/ complete-white-paper-c11-481360.pdf (8.11.2017).

CISCO02, 2016, Raport: Cisco Global Cloud Index: Forecast and Methodology, 2015-2020, http:// www.cisco.com/c/dam/en/us/solutions/collateral/service-provider/global-cloud-index-gci/ white-paper-c11-738085.pdf (8.11.2017).

EY, 2015, Consumerization and the digital enterprise, http://www.ey.com/Publication/vwLUAssets/ ey-consumerization-and-the-digital-enterprise/\$FILE/ey-consumerization-and-the-digital-enterprise.pdf (8.11.2017)

IBM, 2017, https://w3-03.sso.ibm.com/services/lighthouse/bluetube/videos/810, (8.11.2017).

Marr B., 2014, Big Data: The 5 Vs Everyone Must Know, https://uk.linkedin.com/in/bernardmarr, (8.11.2017).

Mateos A., Rosenberg J., 2011, Chmura obliczeniowa. Rozwiazania dla biznesu, HELION S.A., Gliwice

Senior S., Gaut B., Baz B., Stamper J. i in., 2016, AWS Certified Solutions Architect Official Study Guide, John Wiley \& Sons.

STATISTA01, 2017, Raport: Most famous social network sites worldwide as of September 2017, ranked by number of active users (in millions), https://www.statista.com/statistics/272014/global-socialnetworks-ranked-by-number-of-users/ (8.11.2017).

STATISTA02, 2017, Raport: Number of smartphone users worldwide, https://www.statista.com/statistics/330695/number-of-smartphone-users-worldwide/ (8.11.2017).

WATSON, 2017, IBM Watson Analytics, https:/www.ibm.com/watson-analytics (8.11.2017). 